\title{
REGULASI TENTANG PORNOGRAFI: TINJAUAN KONTEKSTUAL HUKUM ISLAM
}

\section{Hamdan*}

\section{Abstract}

The issue and reality of pornography is as old as the civilization of buman beings. The sensitivity of pornography-porno actions in the context of Indonesian society with the biggest number of muslims population in the world is getting hotter along with the plan to regulate the pornography. Procont of pornography is related to definition, criteria and limitation of pornography-porno actions. The polemic becomes more complicated when it is associated with economy, politics, religion, art, etc.

Although it is not a major issue anymore - as it was few months agothis writing aims at giving reflection on pornography dealing with Islamic law mainly on the aspect of law concluding (istinbat al-bukm) and aspect of profit and loss. The reflection of Islamic law on genitals and the reposition of knowledge of Islamic law as individual and social ethic controlled by society and State will be analyzed deeper in this writing.

Keywords: Pornografi, Pornoaksi, Kemaslahatan, Istinbât alHukm.

FENOMENA marak dan merebaknya kasus pornografi-pornoaksi dalam beberapa tahun terakhir ini, merupakan efek langsung dari kebebasan media dalam memberitakan dan memproduksi itemitem pornografi-pornoaksi. Bukan kebetulan, debat tentang pornografi-pornoaksi berbarengan dengan munculnya foto bugil

\footnotetext{
*Penulis adalah alumnus Pascasarjana Universitas Muhammadiyah Yogyakarta konsentrasi Pemikiran Hukum Islam. email: dhani_care@yahoo.com
} 
Sophia Latjuba, aksi bugil Anjasmara dengan Isabell di Museum Bank Indonesia Jakarta Kota dan sederet kasus pelecehan seksual atau asusila di tengah masyarakat, khususnya di kalangan pelajar yang kian menggelisahkan. Realitas ini pun masih ditambah dengan langkah berani terbitnya majalah playboy di Indonesia dan sampai saat ini masih terus berlanjut.

Sementara itu, isu-isu sensitif pornografi-pornoaksi kian bergulir di tanah air seiring dengan wacana pembentukan regulasi tentang pornografi. Beberapa pihak menyakini bahwa regulasi tentang pornografi ini dirasakan penting sebagai tameng moral di tengah arus deras globalisasi dan budaya permisif yang kian tumbuh dalam masyarakat Indonesia. Namun demikian, beberapa pihak yang umumnya adalah para pembisnis, pelaku, pemilik media, atau seniman-seniman tertentu berpendapat sebaliknya, yakni dengan terbitnya regulasi ini, mereka menilai akan sangat memasung kreativitas para seniman, memenjarakan bisnis media, memojokkan perempuan, dan berpeluang meningkatkan kekerasan terhadap perempuan daripada memberi perlindungan. Dengan kata lain, tujuan pembentukan UU bukan melindungi masyarakat, tapi malah mengkriminalkan masyarakat. ${ }^{1}$

Di samping dua kubu pro dan kontra, muncul pula pihakpihak yang tidak memosisikan diri di antara kedua kubu dan seolah-olah memahami bahwa dalam negara multikultur dan multireligi seperti Indonesia, perdebatan tentang pornografipornoaksi tersebut tidak akan menemukan ujung akhir atau titik temu. Kelompok ini, walaupun cenderung permisif, menawarkan perlunya pengaturan hukum yang tegas terhadap pornografipornoaksi dalam bentuk pelarangan-pelarangan tertentu. Hal ini misalnya pada pelarangan aksi-aksi pornografi-pornoaksi untuk tidak dikonsumsi oleh semua kalangan masyarakat, khususnya

${ }^{1}$ Tentang ini, lihat misalnya, Abdul Moqsith Ghazali, "Agama, Seni, dan Regulasi Pornografi”, dalam Republika, Tanggal 26 Agustus 2006, Makmun Murai, 'Mayoritas Diam RUU-APP' dalam Republika, Tanggal 19 Mei 2006. 
anak-anak. Sebagaimana dimaklumi, kontroversi wacana RUU tentang pornografi ini, sebenarnya telah mengalami proses panjang sejak tahun 1999, yakni waktu diajukan pada era Presiden Megawati. Namun kini, di saat pembahasan dan upaya pengesahan RUU ini menjadi UU menuai pelbagai kontroversi dari berbagai pihak. Gencarnya angin kontroversi terhadap rancangan regulasi ini telah ikut mengambangkan isu ini menjelang pengesahannya sejak bulan Juni tahun 2006 kemarin.

\section{Epistemologi dan Pro-Kontra Pornografi-Pornoaksi}

Mengamati lahirnya pornografi-pornoaksi, ternyata tidak lepas dari munculnya kapitalisme dan dunia industri modern. Logika kapitalisme menyatakan bahwa semua yang bisa mendatangkan uang dan menambah kapital harus bisa dikeruk sebanyak-banyaknya, tanpa perlu melihat lagi apakah yang dilakukan itu bertabrakan dengan moralitas, agama, ataupun norma-norma kebenaran. Dunia industri seiring dan seirama dengan kapitalisme yang menjadikan uang sebagai berhala yang dipuja-puja. Maka tidak salah jika ladang ini menjadi sasaran tembak yang demikian diminati oleh para industriwan entertainment yang rakus. ${ }^{2}$

Secara historis, isu pornografi di dunia Barat lebih banyak mengacu pada zaman Renaissance, zaman pencerahan, dan revolusi Perancis. Hal ini karena pada abad ke-16, akar pornografi di dunia Barat dianggap sebagai keseimbangan antara

2Proses modernisasi dan globalisasi dengan arus deras informasi dan komunikasi yang menjadikan materi sebagai fokus manusia dunia sekarang ini, tak terkecuali di Indonesia telah menjadi salah satu kontributor terbesar lahirnya pornografi-pornoaksi. Di samping itu, ideologi materialisme dan sekularisme memberikan andil yang tidak kecil dalam melahirkan tindakantindakan pornografi dan pornoaktif dengan alasan, bahwa apa yang dilakukan merupakan tindakan pribadi (privacy action) dan merupakan ekspresi kebebasan individu yang tidak bisa diatur oleh siapapun, termasuk oleh negara sekalipun. 
bidang politik dan seksual. Pada abad ke-16, Aretino seorang seniman Itali di zaman renaisans membuat sebuah karya termasyhur yang berjudul "I modi", yang secara harfiah berarti postur. I modi melibatkan tiga seniman tenar di zaman renaisans, yaitu Aretino, Guilio Romano, dan Marcantonio Raimondi. Mereka melukis enambelas gambar pada dinding gedung di Vatikan. Keenambelas gambar tersebut mencerminkan berbagai adegan seksual yang mengundang reaksi keras dari pihak gereja pada waktu itu, yaitu Pope Clement VII. ${ }^{3}$

Terkait persoalan etik dan estetik, kini masyarakat disuguhi berbagai foto telanjang dan adegan film yang berorientasi pada dimensi syahwati. Biasanya, para aktris ataupun seniman yang berpose dan berakting erotis berlindung di balik karya seni. Membaca gejala ini, setidaknya peneliti melihat ada empat hal yang niscaya dibedah secara komprehensif, yakni:

1. Tentang makna pornografi yang cenderung memakai episteme agama tertentu. Istilah pornografi yang saat ini dipakai untuk membaca gejala global cenderung memaksakan suatu budaya atas budaya lain. Jika pornografi diartikan sebagai tindakan yang cabul, maka ia telah merampas hakhak orang lain untuk mencari pengetahuan. Padahal, tidak sedikit hadis-hadis yang menjelaskan tentang erotisme yang mengandung pendidikan. Ketentuan ini dalam RUU-APP masuk dalam kriteria bab pengecualian.

3Jika ditelusuri, tujuan utama Aretino mempublikasikan I modi ada dua: pertama, untuk menggambarkan adegan seksual secara hidup dan sesuai dengan istilah pergaulan, dan kedua, untuk mengejek pengadilan agama yang terlibat korupsi. Jadi, karya Aretino ini di dalam pandangan gereja Katolik, telah memanfaatkan seks untuk mengekspos kasus korupsi di kalangan elit. ${ }^{3}$ Dengan demikian, berdasarkan tinjauan ini, dapat dipahami bahwa secara historis I Modi mungkin tidak hanya dimaksudkan sebagai sesuatu yang mengarah pada aspek pornografi an sich, tetapi dimaksudkan juga sebagai simbol gerakan moral masyarakat saat itu. Rizal Munstansyir, "Refleksi Filosofis Atas Pornografi dan Pornoaksi", dalam Jurnal Tarïh Mubammadiyah, Yogyakarta: Edisi V, Januari 2003, 2. 
2. Salah pengertian tentang pornografi akan memunculkan kekerasan baru yakni kriminalisasi. Sesuatu yang semula dianggap biasa dan tidak mengandung syahwat tiba-tiba dimaknai pornografi, semisal lukisan atau relief yang ada di candi Borobudur. Pemaknaan yang keliru akan menimbulkan keresahan kesimpangsiuran makna pornografi itu sendiri.

3. Memvonis kejahatan terhadap kesusilaan atau kesopanan adalah bentuk penindasan baru. Penyempitan arti pornografi memunculkan polemik yang berkepanjangan. Jika pornografi hanya diartikan sebatas sensualitas yang diakibatkan oleh perilaku seseorang yang memakai pakaian sedikit terbuka, maka akibat yang paling nyata adalah semua orang yang memakai pakaian adat akan kena hukuman.

4. Pornografi biasanya dibebankan kepada perempuan. Di sini, perempuan dianggap sumber sensualitas yang akan menimbulkan kemerosotan moral. Perspektif pornografi atas perempuan adalah tindakan yang melanggar hak asasi manusia (HAM) Universal. Problematika yang menyudutkan perempuan seringkali atas nama pornografi-pornoaksi sangat subjektif dan tidak memandang hak-hak seorang manusia. Perempuan diposisikan sebagai sesuatu yang nista, sehingga layak untuk dikerangkeng dengan segala aturan yang mengikat. Sementara, laki-laki adalah makhluk bebas yang berbuat sekehendaknya karena tidak memiliki aturan yang seketat perempuan. ${ }^{4}$

Dalam konteks inilah menurut penulis, pengaturan tentang pornografi-pornoaksi niscaya dilakukan secara objektif, bukan

${ }^{4}$ Masih hangat dalam amatan masyarakat, khususnya kritik tajam para aktivis perempuan terhadap pemerintah kota Tangerang yang menerapkan Peraturan Daerah No. 8 tahun 2005 tentang Pelacuran. Implikasi Perda ini telah memakan korban 11 perempuan yang dituduh sebagai pelacur. Perda tersebut telah mengkriminalkan perempuan berdasarkan prasangka. Lebih jauh, "Perempuan, Perda, dan Domestifikasi," dalam Kompas, Sabtu Tanggal 4 Maret 2006, 6. 
sebaliknya, mengobjektifikasi hal-hal yang bersifat subjektif dan over-reaktif terhadap aksi-aksi tersebut. Satu hal yang pasti dan eksplisit, bahwa sensualitas yang dibatasi RUU-APP adalah sensualitas yang memasuki ruang publik. Karena itu, istilah "dipertontonkan di muka umum," "disiarkan/menyiarkan," maupun "menyebarkan," banyak bertebaran dalam draf RUU tersebut. Sensualitas yang berada di ruang privat, memang tidak boleh dijangkau negara.

Berangkat menuju ketentuan dalam RUU pada awalnya bagian pertama menyatakan, bahwa rumusan definisi pornografi adalah: "substansi dalam media atau alat komunikasi yang dibuat untuk menyampaikan gagasan-gagasan tentang seks dengan cara mengeksploitasi seks, kecabulan, dan atau erotika." Sedangkan (pornoaksi) adalah: "perbuatan yang dilakukan dengan sengaja mempertontonkan atau mempertunjukkan eksploitasi seksualitas, kecabulan, dan atau erotika di muka umum." Rumusan materiil tentang definisi pornografi dan pornoaksi ini memang tak ayal menyisakan kontroversi yang memanas. Definisi ini menuntut penjelasan lebih lanjut karena akan sangat mempengaruhi subjek maupun objek-objek yang dikriteriakan sebagai pornografi atau bukan pornografi. 5

${ }_{5}^{5}$ Definisi secara teoritik di atas memang memperlihatkan ketidakjelasan. Demikian juga dengan interpretasi yang berkembang dalam mendefinisikan pornografi-pornoaksi ini pada sisi empiris telah menuntut berbagai kalangan seperti kaum agamawan, aktivis perempuan, pemerhati media, seniman, artis, maupun kaum ibu-ibu untuk menuangkan ide, pikiran, wawasan, maupun pengalaman masing-masing. Hal ini karena pornografi yang dianggap bukan semata-mata faktor utama munculnya perilaku menyimpang atau melanggar hukum serta norma dalam masyarakat dari beberapa kasus kejahatan perkosaan, merupakan sebuah informasi yang dapat dipersepsi bermacam-macam oleh individu yang melihatnya. Persepsi netral, positif, maupun negatif dapat muncul sesuai dengan persepsi dan kondisi masingmasing individu. Opini ini masih ditambah dengan fakta di beberapa tempat terjadinya akulturasi budaya yang berdampingan dengan sensualitas dan seni di mana telah menjadi senjata terampuh untuk mementalkan pornografi. 
Jika merujuk pada keempat ketentuan yang diungkapkan di atas, maka bisa dipahami bahwa problem pornografi tidak hanya sebatas bahasa yang kabur (multi-interpretatif), tetapi juga mengandung unsur penindasan baru. Pemaknaan atas pornografi-pornoaksi lebih bersifat pemaknaan yang dipaksakan, sehingga menghilangkan keragaman budaya dan keyakinan banyak orang. Pemakaian bahasa pornografi mengandung bahasa politik, perempuan diposisikan sebagai aktor di balik kerusakan moral. Tidak hanya itu, perempuan juga dimaknai sebagai makhluk yang diperlakukan apa saja dengan serangkaian aturan hukum dan moral yang mengikat.

Munculnya perlakuan yang tidak sejajar terhadap perempuan sebagaimana digambarkan di atas, dalam perkembangannya di era modern ini dinilai sangat bertentangan dengan misi luhur dalam deklarasi HAM universal yang seniscayanya diakui oleh tiap-tiap negara di dunia ini. Hal ini karena acuan dalam UU tentang HAM No. 39 tahun 1999 disebutkan:

"Hak Asasi Manusia adalah seperangkat hak yang melekat pada hakikat dan keberadaan manusia sebagai makhluk Tuhan Yang Maha Esa dan merupakan anugerah-Nya yang wajib dihormati, dijunjung tinggi, dan dilindungi oleh negara, hukum, dan setiap orang demi kehormatan serta perlindungan harkat dan martabat manusia."

Oleh beberapa pihak dikatakan, jika menggunakan pendekatan HAM, maka seksualitas merupakan bagian yang tak terpisah dari hak dasar semua manusia, yang mencakup hak untuk mendapatkan kenikmatan seksual, hak untuk mempunyai, dan mengekspresikan identitas seksual, serta hak untuk memegang kendali atas seksualitas pribadi (termasuk hak atas kesehatan seksual dan kesehatan reproduksi) tanpa diskriminasi dan kekerasan. Dalam konteks ini, kontrol terhadap seksualitas

Nampaknya tarik menarik antara argumen agama-moralitas vis a vis kebebasan berekspresi-berkesenian terus mempengaruhi apakah aktivitas seseorang dikatakan pornografi atau mungkin karya seni. 
seseorang, baik oleh negara maupun oleh pelaku nonnegara, merupakan pelanggaran HAM. Menggunakan acuan ini, maka RUU-APP sangat bertentangan dengan HAM. ${ }^{6}$

Sebenarnya argumentasi pelanggaran HAM dalam RUU ini terkait dengan ketentuan dalam konstitusi pada pasal $28 \mathrm{~J}$ ayat (2) amandemen UUD 1945 yang melakukan pembatasanpembatasan tertentu. Ketentuan tersebut menyatakan:

"Dalam menjalankan hak dan kebebasannya, setiap orang wajib tunduk dengan pembatasan yang ditetapkan dengan Undang-Undang dengan maksud semata-mata untuk menjamin pengakuan serta penghormatan atas hak dan kebebasan orang lain dan untuk memenuhi tuntutan yang adil sesuai dengan pertimbangan-pertimbangan moral, nilai-nilai agama, keamanan dan ketertiban umum dalam suatu masyarakat yang demokratis."

Opini yang mengatasnamakan HAM ini seringkali melupakan substansi RUU ini dibuat, bahwa semua aksi-aksi dikategorikan sebagai pornografi-pornoaksi adalah ketika memasuki ruang publik (public sphare) dan meresahkan masyarakat. Peran negara untuk membuat sebuah regulasi yang bermaksud untuk menghormati HAM di satu sisi dan moralitas atau norma-norma sosial di sisi lainnya, agar masyarakat dapat hidup teratur dan terciptanya soliditas kelompok atau masyarakat tersebut.

Namun demikian pada sisi lain, jika pornografi-pornoaksi hanya memakai bahasa politik, maka akan memunculkan ketidakpastian hukum. Munculnya subjektifitas hukum yang semua orang akan menghakimi, bahwa segala perbuatan yang

${ }^{6}$ Menurut Radhika Coomaraswamy, Ketua Komnas HAM Srilanka dan mantan Pelapor Khusus PBB tentang kekerasan terhadap perempuan, hak seksual merupakan jenis hak generasi terbaru yang masih perlu dikembangkan pemahamannya dan diintegrasikan ke dalam mekanisme HAM internasional. Lihat dalam presentasi pada "International Consultation on Women Human Rights Defenders", Tanggal 29 November-1 Desember 2005, Kolombo, Srilanka. 
mengarah pada aksi-aksi erotisme adalah pornografi-pornoaksi juga akan menyebabkan peraturan ini akan mengalami kesewenang-wenangan dalam ranah penegakan hukum. Bahasa dan kultur politik yang membingkai istilah pornografi-pornoaksi tersebut akan memunculkan kekerasan struktural yang bersifat kolektif dan malah dilegitimasi oleh negara dan masyarakat yang sama-sama memvonis segala sesuatu yang bersifat subjektif. Kekerasan struktural muncul ketika negara dengan dengan berbagai perangkat legal-normatif hukum yang ditetapkan menimbulkan ketidaknyamanan, bahkan distabilitas sosial bagi pihak-pihak tertentu. $^{7}$

Berdasarkan fakta-fakta di atas, maka rancangan regulasi tentang pornografi-pornoaksi ini, sesuai dengan ketentuan dalam bagian "menimbang" disebutkan, bahwa meningkatnya pembuatan, penyebarluasan, dan penggunaan pornografi serta penyelenggaraan pornoaksi dalam masyarakat saat ini sangat memprihatinkan dan dapat mengancam kelestarian tatanan

${ }^{7}$ Pada sisi lain, munculnya reaksi masyarakat terhadap pornografipornoaksi merupakan respon sosial dan moral yang ditujukan terhadap fakta sosial yang dinilai menyimpang dan tidak sesuai atau melanggar nilai etis. Pada dimensi penegakan hukum, kasus pornografi secara prosesual terkait dengan UU No. 8 tahun 1981 tentang KUHAP dan secara material terkait dengan KUHP. Permasalahan yang sering muncul dalam penegakan hukum terhadap permasalahan pornografi-pornoaksi selama ini tidak lepas dari sistem penegakan hukum secara umum, baik mental aparat, hukum acara, tersedianya fasilitator advokasi, kondisi masyarakat, kondisi politik, ekonomi, sosial, budaya, dan substansi dari perangkat hukum.Kelompok yang setuju dengan proses rancangan regulasi ini, meskipun dengan beberapa catatan revisi secara tegas menyatakan, bahwa secara faktual pornografi-pornoaksi telah menimbulkan berbagai implikasi negatif bagi kelangsungan kehidupan bangsa ini secara keseluruhan. Akses negatif pornografi-pornoaksi telah membuat dekadensi moral, tatanan keluarga, dan kehidupan masyarakat yang menjunjung tinggi nilai-nilai moral dan agama, seperti; maraknya pergaulan bebas, perselingkuhan, kehamilan dan kelahiran anak di luar nikah, aborsi, penyakit kelamin, kekerasan seksual, perilaku seksual menyimpang, dan lain sebagainya. 
kehidupan masyarakat yang dilandasi nilai-nilai Ketuhanan Yang Maha Esa. Ketentuan dalam poin pertimbangan tersebut didahului oleh konsepsi bahwa negara Republik Indonesia merupakan negara hukum yang berlandaskan Pancasila yang lebih mengutamakan kepentingan umum daripada kepentingan pribadi dan untuk mewujudkan tatanan masyarakat Indonesia yang serasi dan harmonis dalam keanekaragaman suku, agama, ras, dan golongan/kelompok, diperlukan adanya sikap dan perilaku masyarakat yang dilandasi moral, etika, akhlak mulia, dan kepribadian luhur yang beriman dan bertaqwa kepada Tuhan Yang Maha Esa. ${ }^{8}$

Dengan dibentuknya regulasi tentang pornografi, maka upaya penegakan dan penataan budaya hukum dalam suatu masyarakat diharapkan makin jelas dan aplikatif di masa-masa mendatang. Bukankah sekian banyak perkara, termasuk kasus pornografi yang nyata-nyata merusak moral generasi dan anakanak bangsa ini ternyata tidak dapat pertanggungjawaban secara yuridis. Hal ini karena disparitas keadilan hukum di Indonesia masih banyak berkorelasi dengan variabel kekuatan ekonomi dan kekuasaan politik.

${ }^{8}$ Lihat RUU tentang Pornografi bagian, menimbang a, b, dan c. Bagian "menimbang" ini dianggap penting karena biasanya memuat sisi landasan filosofis, politis, atau sosiologis. Rumusan dalam bagian inilah yang akan memberikan jiwa kepada bagan batang tubuh suatu UU, karena rumusan tersebut adalah hasil dari pemahaman atas realitas sosial. Dengan demikian, rumusan dalam bagian ini akan sangat menentukan apakah sebuah peraturan perundang-undangan memiliki basis legitimasi sosial secara luas ataukah hanya disenangi atau hanya untuk membela segelintir elit politik, pihak-pihak tertentu atau kelompok agama masyarakat tertentu. RUU ini diharapkan dapat mencegah terjadinya kerusakan tatanan dan disintegrasi yang disebabkan oleh tindakan-tindakan asusila, amoral, maupun asosial yang dilakukan oleh sekelompok individu dengan gagasan-gagasan ke lingkungan publik. Lihat misalnya, Evi Sofia Inayati, "Permasalahan Masyarakat dan Kegemaran Terhadap Pornografi: Kajian Pustaka" dalam Jurnal Tarjih, Edisi ke 5, Januari 2003, 12-3. 


\section{Formulasi Pornografi-Pornoaksi: Perspektif Hukum Islam}

Sebelum melangkah lebih mendalam tentang bagaimana hukum Islam memandang permasalahan pornografi dan pornoaksi ini, maka hal pertama sebagai bagian pembahasan ini adalah bagaimana memahami hukum Islam secara normatif khususnya proses istinbât hukum terhadap suatu permasalahan. Ini menjadi keniscayaan dalam konteks keseluruhan ajaran Islam guna menghindari cara ijtihad yang atomistik-parsial. Selama ini kita telah merasa puas untuk mendasarkan argumentasi dalam memahami agama, atau lebih khusus dalam istinbât hukum kepada satu atau dua potong dalil, baik berupa ayat-ayat alQuran dan atau hadis-hadis Nabi saja tanpa melihat dan mempertimbangkan wawasan dasar ajaran agama Islam (fundamental values) dan tujuan umum serta prinsip-prinsip pokok syari'at (shariah principles) secara utuh.

Bagi umat Islam, al-Qur'an dan Sunnah merupakan sumber hukum asasi atau sumber dari segala sumber hukum yang merupakan elemen fundamen dalam menyakini kebenaran syariah itu sendiri. Keduanya berlaku universal dan internal untuk segala tempat dan waktu, serta menjadi norma-norma yang menjamin kemaslahatan umat manusia di dunia dan di akhirat. Kemaslahatan ini sejalan dengan misi rahmat atau kemaslahatan dalam Islam sebagaimana ditegaskan dalam firman Allah swt. Qs. al-Anbiyâ' (21): 107.9

Hikmah atau tujuan utama dari hukum-hukum syari'at tidak lain adalah untuk memberikan kesejahteraan, kedamaian, ketenangan, dan kebahagiaan hidup manusia, baik di dunia maupun akhirat. Dengan ayat di atas, ulama menetapkan bahwa sistem hukum Islam ditegakan atas prinsip peniadaan kesulitan (masyaqqab), penjamin kemaslahatan manusia secara umum, dan wahana mewujudkan keadilan yang menyeluruh bagi semua

9Terjemahannya: "Dan tiadalah Kami mengutus engkau (Muhammad) kecuali untuk (menjadi) rahmat bagi semesta alam”. 
umat manusia. ${ }^{10}$ Tujuan filosofis dan fundamen untuk memberikan kesejahteraan, kedamaian, ketenangan, dan kebahagiaan hidup manusia dalam syari'at. Secara filosofis RUU pornografi bertujuan untuk mewujudkan tatanan masyarakat Indonesia yang serasi dan harmonis dalam keanekaragaman suku, agama, dan golongan/kelompok. Di sinilah relevansi adanya sikap dan perilaku masyarakat yang dilandasi moral, etika, akhlak mulia, dan kepribadian luhur.

Namun demikian, prinsip-prinsip tersebut disadari tidak lepas dari bagian-bagian parsialnya. Dengan kata lain, prinsip umum syariat tersebut terbentuk dari generalisasi kasus-kasus detail. Hal ini persis seperti hubungan fiqh sebagai hukum juz $\hat{\imath}$ dan kaidah-kaidah fiqh sebagai hukum kulli. Kaidah-kaidah fiqh disimpulkan secara induktif dari kumpulan sejumlah hukum fiqh detail (hukum juz i). Sebaliknya hukum fiqih detail itu pula pada gilirannya ikut dibentuk oleh dan dilahirkan berdasarkan kaidahkaidah fiqh yang merupakan hukum kulli. Kondisi demikian juga terdapat dalam hubungan antara kaidah penafsiran al-ibrah bi 'umûm al-laf̧̧ lâ bi khushûsh al-sabab (pemahaman/penafsiran berdasarkan keumuman pernyataan, bukan berdasarkan kasus yang khusus) di satu pihak dengan teori asbâb al-nu₹̂̂l (latar belakang turunnya ayat al-Quran) atau asbâb wurûd al-hâdîts (latar belakang munculnya sebuah hadis) di pihak lain.

Konsepsi yang diterangkan di atas sejalan dengan pembagian norma-norma hukum Islam seperti nilai-nilai filosofis, normanorma yang berwujud qawâid fiqhiyyah dan nazariyât al-fiqhiyyah dan terakhir peraturan-peraturan hukum konkret sebagai implementasi dari kedua norma-norma sebelumnya, maka penelitian normatif hukum Islam tersebut dapat dibagi menjadi, a) penelitian filosofis, b) penelitian doktrinal, dan c) penelitan klinis, yakni penemuan hukum syar'i untuk menemukan jawaban

${ }^{10} \mathrm{Al}$-Ghazâlî, al-Musthasfâ min 'Tlm al-Uhsûl al-Fiqh, Jilid I (Bagdad: Musannâ, 1970), 284. 
konkret dari permasalahan hukum yang ada di masyarakat. ${ }^{11}$ Dalam memahami suatu teks, umat Islam harus berpegang kepada pernyataan umum teks itu sendiri, yang berarti kita harus melampaui situasi-situasi khusus di sekitar teks itu. Namun di lain pihak kita tidak dapat melepaskan sama sekali situasi khusus itu. al-Syâtibi mengatakan, "Barang siapa berpegang kepada suatu nash mengenai suatu kasus parsial, tanpa mempertimbangkan prinsip umum yang berlaku dalam kasus tersebut adalah keliru, sebagaimana juga keliru dengan orang yang hanya memegangi prinsip umum tanpa mempertimbangkan keadaan yang khusus."12

Ini artinya, apabila ketentuan tersebut diterapkan dalam memahami dan memberikan penilaian terhadap pornografipornoaksi dari perspektif hukum Islam, maka tidak cukup mencari satu atau dua dalil untuk menjadi dasar argumentasi tentang hukum kedua hal tersebut. Sebaliknya, harus menempatkan ijtihad mengenai pornografi dan pornoaksi itu dalam konteks lebih luas, meliputi keseluruhan wawasan dasar Islam dan tujuan umum serta prinsip-prinsip pokok syariat. Dengan demikian, hasil ijtihad hukum itu diharapkan lebih komprehensif.

Langkah komprehensif dalam Islam ini jika ditarik dalam konteks penanggulangan pornografi ini memunculkan pula gugatan dari beberapa kalangan bahwa semestinya pemerintah menanggulangi akar permasalahan maraknya pornografi dan pornoaksi di tengah masyarakat. Sekalipun mempunyai pasalpasal yang bagus, RUU ini belum tentu akan bisa memerangi pornografi-pornoaksi, ketika akar permasalahannya tidak dipahami dan ditanggulangi terlebih dahulu. Memang

${ }^{11}$ Syamsul Anwar, "Pengembangan Metode Penelitian Hukum Islam," dalam Neo Usul Fiqib: Menuju Ijtihad Kontekstual, (Yogyakarta: Fak. Syari'ah Press \& FSHI, 2004), 189-191.

${ }^{12}$ Abû Ishâq al-Syatîbî, al-Muwâfaqât fi Ushûl al-Ahkâm, Jilid III (t.t.p.: Dâr al-Fikr, $1341 \mathrm{H}), 3$. 
pemerintah bukan entitas yang pasif-defensif, melainkan harus pro-aktif.

Dalil-dalil syar'i harus digunakan secara bersama-sama sehingga menghasilkan pemahaman yang luas dan komprehensif. Atau dalam bahasa yang lebih sederhana, inilah cara berfikir syari'at yang berdasarkan kepada apa yang disebut induksi tematik (istiqrâ' ma'nâm $)$, baik dari sisi materiil syari'at maupun semangat syari'at itu sendiri. Dalil-dalil yang terlibat barangkali tidak semuanya langsung mengenai permasalahannya. Hanya saja dukungan subsidernya terhadap masalah tersebut membawa kepada suatu kesimpulan yang benar-benar bersifat menyeluruh. Kaidah menarik dalam hadis Rasulullah: لاضررو لاضرار (janganlah melakukan sesuatu yang berbahaya dan membahayakan). Demikian juga dengan kaidah fiqh lain yang berbunyi; كل من يتولد من الحرام فهو الحرام (Setiap sesuatu yang lahir (timbul) dari sesuatu yang haram adalah haram). ${ }^{13}$ Demikian juga pada tataran ushul fiqh dikenal adanya sumber hukum-walaupun berstatus sekunder dan bukan primer-yakni penerapan argumentasi hukum sadd al-dzarîah yang menyatakan, bahwa semua hal yang dapat menyebabkan terjadinya perbuatan haram adalah haram.

Mengenai diskursus pornografi dan pornoaksi ini, terdapat beberapa landasan normatif (nasshiyyah-qath'iyyah) di dalam alQur'an yang memberikan terapi awal agar kaum mukminin terhindarkan dari perilaku seks menyimpang, seperti firman Allah dalam Qs. al-Nûr (24): 30-31 yang terjemahannya:

"Katakanlah kepada laki-laki yang beriman, "Hendaklah mereka menahan pandangannya dan memelihara kemaluannya; yang demikian itu adalah lebih suci bagi mereka, sesungguhnya Allah Maha Mengetahui

13Pengharaman zina misalnya, selain tentu saja melarang perbuatan zina itu sendiri, namun al-Quran dengan sangat melarang perbuatan-perbuatan yang akan membuat pelakunya akan berbuat zina karena perbuatan pengantar zina yang dia lakukan. Larangan preventif ini tercantum dalam alQur'an, al-Isrâ' (17): 32. 
apa yang mereka perbuat. Katakanlah kepada wanita beriman, "Hendaklah mereka menahan pandangannya dan memelihara kemaluannya, dan janganlah mereka menampakkan perhiasannya kecuali yang (biasa) nampak daripadanya. Hendaklah menutupkan kain kudung ke dadanya, dan janganlah menampakkan perhiasannya kecuali kepada suami mereka, atau ayah mereka, atau ayah suami mereka, atau putraputra mereka, atau putra-putra suami mereka, atau saudara laki-laki mereka, atau putra saudara laki-laki mereka, atau putra saudara perempuan mereka, atau perempuan Islam, atau budak yang mereka miliki, atau pelayan laki-laki yang tidak mempunyai keinginan (terhadap wanita), atau anak yang belum mengerti tentang aurat wanita. Dan janganlah mereka memukulkan kakinya agar diketahui perhiasan yang mereka sembunyikan, dan bertaubatlah kepada Allah wahai orang-orang yng beriman supaya kamu beruntung."

Ketentuan dalam ayat di atas secara tegas menjelaskan tentang dua aspek kehidupan manusia, yaitu hukum dan sosial. Dalam aspek hukum, Allah menjelaskan tentang disyari'atkannya hijab dan berbicara, terutama tentang hal-hal lain yang berkaitan dengan seluk beluk wanita, mulai dari aurat, batasan yang boleh dilihat dan yang tidak boleh. Sedang dalam aspek sosial, ayat ini berbicara tentang aturan hubungan lawan jenis dan akibat-akibat yang ditimbulkan jika aturan tersebut dilanggar. Syari'at memerintahkan untuk menutup bagian-bagian tubuh tertentu dari tubuh manusia, atau yang dalam bahasa fiqh disebut aurat.

Demikian juga dengan apa yang dikemukakan-Nya yang memiliki keterkaitan dengan penyimpangan seksual umat manusia, yakni Qs. al-Syu’arâ (26): 165-6 yang terjemahannya:

"Mengapa kamu mendatangi jenis laki-laki di antara manusia, dan kamu tinggalkan istri-istri yang dijadikan oleh Tuhan-mu untukmu, bahkan kamu adalah orang-orang yang melampui batas."

Sementara itu, terdapat beberapa hadis Nabi saw. yang berkaitan dengan permasalahan pornografi dan pornoaksi yang diriwayatkan oleh 'Aisyah ra. bahwa Rasul bersabda:14

${ }^{14}$ Abû Dâwûd, Sunan Abû Dâwûd, "Kitâb al-Libâs Bâb Fî Mâ Tubdi alMar'ah Min Zinatiha”, Hadis No. 3580. 

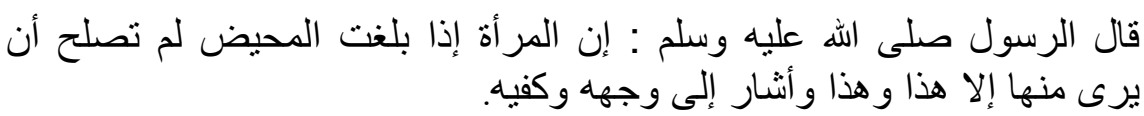

Artinya: "Rasulullah bersabda: sesungguhnya seorang wanita apabila telah baligh (haid), maka tidak boleh baginya menampakkan tubuhnya kecuali ini dan ini, seraya menunjuk ke wajah dan telapak tangan.”

Hadis ini secara tegas menyatakan aurat wanita, yakni seluruh bagian tubuh wanita selain muka dan telapak tangan adalah haram, kecuali dalam kondisi-kondisi tertentu yang dibenarkan secara syari'at. Di samping itu, masih terdapat hadis-hadis yang juga membicarakan tentang aurat wanita dan laki-laki yang seharusnya ditutupi dan tidak diperkenankan untuk dibiarkan terbuka, apalagi dikomersilkan dengan motif atau alasan apapun. Hadis ini dapat dikatakan juga memperkuat ketentuan dalam Qs. al-Nûr ayat: 30-1 di atas. Hal ini karena jika diperhatikan, kalimat illâ mâ drahara minhâ (kecuali yang biasa nampak dari padanya) menurut ulama tafsir yakni anggota tubuh yang boleh ditampakkan, yakni wajah dan dua telapak tangan. Demikianlah pendapat sebagian sahabat, seperti 'Aisyah, Ibn Abbas, dan Ibn Umar. Ibn Jarîr al-Thabârî berkata dalam kitab tafsirnya Jâmi’ alBayân fi Tafsîr Al-Qur'ân mengenai apa yang dimaksud dengan "kecuali yang (biasa) nampak dari padanya", bahwa pendapat yang paling mendekati kebenaran adalah yang wajah dan dua telapak tangan." Pendapat yang sama juga dinyatakan Imam alQurthûbi dalam kitab tafsirnya Al-Jâmi“ li Ablkâm Al-Qur'ân. ${ }^{15}$

15Ketentuan ini sejalan dengan apa yang dikemukakan dalam usulan UU tentang Pornografi Pasal 25 (1) bahwa setiap orang dewasa dilarang mempertontonkan bagian tubuh tertentu yang sensual. Bagian tubuh yang sensual ini dijelaskan dalam penjelasan Pasal 4, bahwa yang dimaksud dengan bagian tubuh tertentu yang sensual antara lain adalah alat kelamin, paha, pinggul, pantat, pusar, dan payudara perempuan, baik terlihat sebagian maupun seluruhnya. Apa yang dikemukakan dalam pasal ini walaupun dalam pembahasannya mengalami perbedaan persepsi masyarakat antara kriteria porno dan tidak sopan (indecent). Franz Magnis Suseno, "Sekitar RUU Anti Pornogrrafi”, dalam Kompas, Tanggal 27 Februari 2006. 
Satu hal yang pasti dalam ranah hukum Islam dan menjadi kesepakatan ulama, bahwa aurat perempuan adalah seluruh tubuhnya kecuali muka dan telapak tangan. Islam memperkenankan kepada setiap muslim, bahkan menyuruh supaya geraknya baik, elok dipandang dan hidupnya teratur dengan rapi untuk menikmati perhiasan dan pakaian yang telah dicipta Allah. Adapun tujuan pakaian dalam pandangan Islam ada dua macam: yaitu untuk menutup aurat dan berhias. Ini adalah merupakan pemberian Allah kepada umat manusia seluruhnya, di mana Allah telah menyediakan pakaian dan perhiasan dan diharapkan umat muslim dapat mengaturnya sendiri. Allah swt. berfirman dalam Qs. al-A'râf (7): 26 yang terjemahannya:

"Wahai anak Adam, sesungguhnya Kami telah menurunkan kepadamu pakaian untuk menutupi auratmu dan pakaian yang indah untuk perhiasan."

Dengan demikian, barangsiapa yang mengabaikan salah satu dari dua perkara di atas, yaitu berpakaian untuk menutup aurat atau berhias, maka sebenarnya orang tersebut telah menyimpang dari ajaran Islam dan mengikuti jejak setan. Inilah rahasia dua seruan yang dicanangkan Allah kepada umat manusia, sesudah Allah mengumandangkan seruan-Nya yang terdahulu itu, di mana dalam dua seruan-Nya itu Allah melarang keras kepada mereka telanjang dan tidak hendak berhias, yang justru keduanya itu hanya mengikuti jejak setan belaka. ${ }^{16}$

Kondisi terbuka aurat atau berpakaian ketat atau tembus pandang inilah yang dapat membangkitkan nafsu birahi dan jika tidak diatur, akan berdampak negatif bagi umat Islam dan bangsa Indonesia umumnya, terutama anak-anak dan generasi muda. Timbulnya pergaulan bebas, perselingkuhan, kehamilan, kelahiran anak di luar nikah, aborsi, penyakit kelamin, kekerasan

${ }^{16}$ Yusuf al-Qaradhawi, Halal dan Haram dalam Islam, ter. Mu'ammal Hamidy (Surabaya: Bina Ilmu, 1993), 40. 
seksual, perilaku seksual menyimpang, dan lain sebagainya. Membiarkan kasus-kasus dan ekses negatif ini berkembang dapat berakibat pada kehancuran bangsa dan inilah klausul yang menyebabkan perlunya sesegera mungkin untuk melakukan tindakan preventif dan penghentiannya berupa regulasi perundang-undangan yang memuat ancaman hukuman yang berat sekaligus tegas.

Hal lainnya yang merupakan dasar metodologi istinbât hukum adalah mempertimbangkan kemaslahatan seluruh masyarakat. Hukum bukanlah proyeksi dari klaim-klaim subjektivitas segelintir orang atau intervensi pola kehidupan dan atau paradigma tertentu, termasuk isu kultur yang menjadi dalih terkuat masyarakat tertentu untuk mempengaruhi kehidupan orang lain. Subjektivitas beberapa pihak dalam menjustfikasi ketidaksetujuan terhadap regulasi pornografi adalah dalih seni dalam karya-karya pornografi-pornoaksi. Padahal jika merujuk definisi menurut Kamus Besar Bahasa Indonesia (KBBI), seni adalah karya yang diciptakan dengan keahlian yang luar biasa. Apakah pamer aurat dengan tidak merasa malu bisa disebut seni? Begitu banyak media cetak maupun elektronik memuat adeganadegan atau gambar-gambar yang tidak pantas untuk dilihat masyarakat. Realita ini tentu bertentangan dengan semangat dan substansi penyiaran sebagaimana tercantum dalam pasal 36 ayat (1) UU No. 32 tahun 2002 tentang Penyiaran dikatakan; isi siaran harus mengandung informasi, pendidikan, hiburan, dan manfaat untuk pembentukan intelektual, watak, moral, kemajuan, kekuatan bangsa, menjaga persatuan dan kesatuan, serta mengamalkan nilai-nilai agama dan budaya Indonesia.

Sesuai dengan ketentuan pelarangan pornografi pada Pasal 4 dinyatakan, "setiap orang dilarang membuat tulisan, suara atau rekaman suara, film atau yang dapat disamakan dengan film, syair lagu, puisi, gambar, foto, dan atau lukisan yang mengeksploitasi daya tarik bagian tubuh tertentu yang sensual dari orang dewasa." Pelarangan ini sesungguhnya merupakan 
penjabaran dari defenisi pornografi dan pornoaksi yang mengkategorikan substansi dalam media atau alat komunikasi yang dibuat untuk menyampaikan gagasan-gagasan yang mengeksploitasi seksual, kecabulan, dan atau erotika.

Namun, realitas di tanah air kian tidak jelas dan tegas batasan sesuatu dikategorikan seni atau obyek pornografi. Bahkan ketika diskursus ini hangat diperbincangkan, nampak bagaimana dalih seni atau nilai estetika oleh sebagian kalangan seniman, artis, bahkan pihak-pihak yang sealiran terus digalakkan dalam menyebarluaskan pornografi. Nilai-nilai etika, moral, dan spiritual bangsa lebih rendah manfaatnya daripada nilai-nilai material-benda-uang, sehingga dapat dikalahkan oleh nilai-nilai komersial dan kapital dari bisnis aksi-aksi, seni, majalah, maupun substansi media yang memberitakan sisi pornografi.

Dengan pemaparan materiil dari RUU tentang pornografi di atas, maka dapat ditegaskan beberapa hal, yakni;

a. Kebebasan dan kreativitas yang diusung seseorang tidak bisa disalahgunakan dengan tindakan ekspresif yang bertentangan dengan norma-norma dan etika masyarakat. Kata-kata "tubuhku adalah milikku" jelas merepresentasikan aksentuasi subjektivitas kebebasan dan berkreasi tanpa memperhatikan kepentingan sosial masyarakat yang lebih luas.

b. Seni-terutama di negara-negara yang memiliki nilai-nilai adat dan etika keagamaan-sangat terkait erat dengan etika. Keduanya ibarat dua sisi uang logam. Tindakan manusia masuk domain nilai etis, maka kebebasan berekspresi dalam berkesenian harus dalam batas-batas etika yang berlaku. Seseorang tidak bisa melakukan pelanggaran etika sosial dengan mengatasnamakan seni;

c. Intergasi etika dalam seni akan melahirkan hasil karya yang bernilai seni dan estetika tinggi dan berdampak positif bagi masyarakat.

Persoalan pornografi dalam ranah publik memang telah menjadi permasalahan yang memerlukan beragam perspektif 
dan cara pandang keilmuan, di samping kondisi objektif, peran pemerintah maupun masyarakat seluruhnya. Isu pemakaian koteka, seni, kriminalisasi perempuan, maupun adat istiadat suatu masyarakat memang harus diperhatikan oleh pemerintah. Inilah yang selanjutnya diatur pemerintah dengan menetapkan adanya beberapa pengecualian terhadap pornografi. Pada pasal 34 sampai pasal 36 dicantumkan, bahwa pembuatan, penyebarluasan, dan penggunaan pornografi dikecualikan untuk tujuan pendidikan dan atau pengembangan ilmu pengetahuan dalam batas yang diperlukan pada lembaga riset atau lembaga pendidikan yang bidang keilmuannya yang bertujuan untuk pengembangan pengetahuan untuk keperluan pengobatan dan adanya rekomendasi dari dokter, rumah sakit, dan atau lembaga kesehatan yang mendapatkan ijin dari pemerintah

Bukankah tujuan syari'at Islam adalah memberikan perlindungan terhadap lima hal, atau dalam konsep al-Syatîbî disebut dimensi kemaslahatan utama (al-maslabah al-asâsiah) yakni perlindungan terhadap agama (din), perlindungan terhadap jiwa (nafs), perlindungan terhadap akal ('aql), perlindungan terhadap anak keturunan (nasl), dan perlindungan terhadap harta benda serta kehormatan (mâl). ${ }^{17}$ Sementara itu, Imam al-Ghazâlî mengemukakan bahwa pada prinsipnya maslahah adalah mengambil manfaat dan menolak kemudharatan dalam rangka memelihara tujuan-tujuan syara'. Imam al-Ghazâlî memandang bahwa suatu kemaslahatan harus sesuai dengan tujuan syara', sekalipun bertentangan dengan tujuan-tujuan manusia, karena kemaslahatan manusia tidak selamanya didasarkan pada kehendak syara', tetapi sering kali didasarkan pada kehendak hawa nafsu. Tujuan yang harus dipelihara tersebut, lanjut alGhazâlî ada lima bentuk, yaitu memelihara agama, jiwa, akal, keturunan, dan harta. ${ }^{18}$

${ }^{17}$ al-Syâtîbî, al-Muwâfaqât ..., Jilid II, 8., juga Subhi Mahmasani, Filsafat Hukum Islam, ter. Ahmad Soejono (Bandung: al-Ma'arif, 1976), 215.

18al-Ghazâlî, al-Musthasfâ..., 286. 
Pertimbangan lain yang layak diajukan dalam konteks hukum Islam yakni, bahwa secara akal sehat masyarakat dapat menilai unsur keburukan (taqbîh) yang lebih dominan daripada unsur kebaikan (tahsin) dalam permasalahan pornografi tersebut. Ini berkaitan dengan teori ta'lîl, yaitu sebuah pemberlakuan syari'at yang didasari pada tujuan tertentu yang tertuang dalam 'illat hukum. Dalam epistemologi burbânî, akal mempunyai peran signifikan dalam mencari sebuah 'illat hukum dengan pertimbangan kemaslahatan. Dalam kaidah fiqh dikatakan; albukmu yadûru ma'a al-illati wujûdan wa 'adaman (suatu bukum ditetapkan sesuai dengan tujuan tertentu, baik yang eksplisit maupun implisit). Jadi, selama 'illat hukum terlihat, maka ketentuan hukum berlaku dan begitu juga sebaliknya. ${ }^{19}$

Apa yang diidealkan oleh syari'at dapat menjadi pertimbangan umat muslim dalam melakukan kontrol sosial moral terhadap liberalisasi seksualitas dan kemaksiatan di ruangruang publik. Suatu jaringan perlindungan masyarakat inilah yang juga dijadikan pertimbangan dan landasan filosofis munculnya Peraturan Daerah (Perda-perda) yang berupaya memberantas kemaksiatan dan penyakit masyarakat lainnya di berbagai wilayah, tentunya setelah melakukan tahapan penjajakan dan sosialisasi terhadap masyarakat setempat.

Berbicara mengenai dampak pornografi, maka akan jelas terlihat akses negatif aksi-aksi ini dalam pengrusakannya terhadap agama, di mana para pelakunya akan semakin menipis komitmen keaagamaannya karena melakukan pelanggaran yang disengaja. Para penikmat pornografi jelas-jelas melakukan perbuatan yang mendekatkan dirinya pada perzinahan yang akan merusak moralitas akhlaknya, menimbulkan penyakit, kehancuran, maupun hilangnya kehormatan sebagai manusia atau dalam konteks kemaslahatan, pornografi, dan pornoaksi

${ }^{19}$ Yusdani, Peranan Kepentingan Umum dalam Kontekstualisasi Hukum: Kajian Konsep Hukum Islam Najamuddin at-Thufi (Yogakarta: UII Press, 2000), 111. 
akan menyebabkan kerusakan pada sisi agama, jiwa, akal, kehormatan, bahkan keturunan di masa mendatang. Misi utama rancangan regulasi ini lebih mengutamakan kepentingan umum daripada kepentingan pribadi dan merupakan kebutuhan fundamental bagi bangsa Indonesia yang secara filosofis merupakan 'jawaban' atas kebutuhan masyarakat transisi. Bukankah masyarakat transisi di manapun selalu rentan terhadap pelbagai perubahan gejala sosial dan budaya baru.

\section{Catatan Akhir}

Berangkat dari seluruh kajian pada permasalahan regulasi tentang pornografi di atas, maka setidaknya ada beberapa simpulan, yakni:

Pertama, Islam berdasarkan ketentuan keseluruhan ayat alQuran dan hadis-hadis Nabi, secara eksplisit maupun implisit melarang semua bentuk aktivitas dan gerak langkah yang mengarahkan setiap orang ke sisi pornografi-pornoaksi.

Kedua, secara definitif permasalahan tentang apa, kriteria dan batasan-batasan pornografi dalam konteks masyarakat yang multikultur niscaya dirumuskan secara arif dan sesuai dengan akal sehat. Jadi, dalih-dalih atas nama seni, adat, pariwisata, HAM, politis, maupun kepentingan bisnis/ekonomi niscaya diletakkan dalam kerangka etika agama, moral kemanusiaan, dan akal sehat.

Ketiga, rancangan regulasi tentang pornografi merupakan salah satu usaha efektif pemerintah dan masyarakat dalam kerangka hukum nasional dengan upaya merangkul kepentingan pihak-pihak dalam masyarakat. Kajian fiqh kontekstual, di samping berposisi sebagai etika individual yang diserahkan penerapannya kepada kesadaran individual, fiqh juga dapat ditempatkan sebagai etika sosial yang diurus oleh masyarakat atau negara. Memang harus diakui, persoalan dekadensi moral tidak cukup dengan diseminasi sebuah regulasi, tetapi paling tidak telah menjadi ikhtiar untuk mengurangi penyakit 
modernitas (the agony of modernity) berupa kerusakan dan kehancuran moral dalam masyarakat.

\section{Daftar Pustaka}

Abdul Moqsith Ghazâli, "Agama, Seni, dan Regulasi Pornografi”, dalam Republika, Tanggal 26 Agustus 2006. Abû Dâwûd, Sunan Abû Dâwûd (Beirût: Dâr al-Fikr, t.t.). Abû Ishâq al-Syâtibi, al Muwâfaqât fi al--Ushâl al--Abhkâm (t.t. p: Dâr al- Fikr, $1341 \mathrm{H}$ ).

Draft Rancangan Undang-Undang tentang Pornografi dan Pornoaksi.

Evi Sofia Inayati, "Permasalahan Masyarakat dan Kegemaran Terhadap Pornografi: Kajian Pustaka”, dalam Jurnal Tarjih, Edisi ke 5, (Januari 2003).

Franz Magnis Suseno, "Sekitar RUU Anti Pornogrrafi", dalam Kompas, Tanggal 27 Februari 2006.

al-Ghazâli, al-Mustashfâ min Tlm al-Ushûl al-Fiqh (Bagdad: Musanna, 1970).

Keputusan Fatwa MUI No. 287 Tahun 2001 tentang Pornografi dan Pornoaksi.

Makmur Noor, "Mayoritas Diam Pro RUU APP", dalam Republika, Tanggal 19 Mei 2006.

Muladi, "Pengembangan Hukum Pidana dalam Konteks Negara Kebangsaan”), dalam Pidana Islam di Indonesia Peluang, Prospek dan Tantangan, ed. Jaenal Arifin dan M. Arskal Salim (Jakarta: Pustaka Firdaus, 2001).

al-Qurthûbî, al-Jâm li al-Ahkâm al-Qur'ân (Beirut: Dâr al-Fikr, t.t.) Radhika Coomaraswamy, "International Consultation on Women Human Rights Defenders", Kolombo, Tanggal 29 November-1 Desember 2005.

Rizal Munstansyir, "Refleksi Filosofis Atas Pornografi dan Pornoaksi", dalam Jurnal Tarjih Mubammadiyah, Edisi ke 5, Januari 2003. 
Subhi Mahmasani, Filsafat Hukum Islam, ter. Ahmad Soejono (Bandung: al-Ma'arif, 1976).

Tim Universitas Udayana, "Pembahasan RUU APP dalam Perspektif Budaya, Sosiologi, dan Hukum", dalam Rumusan Hasil Seminar Universitas Udayana Bali, Tanggal 21 Februari 2006.

Undang-Undang No. 32 Tahun 2002 tentang Penyiaran.

Undang-Undang No. 39 Tahun 1999 tentang Hak Asasi Manusia.

Yusdani, Peranan Kepentingan Umum dalam Kontekstualisasi Hukum:

Kajian Konsep Hukum Islam Najamuddin at-Thufi (Yogakarta: UII Press, 2000).

Yusuf al-Qaradhawi, Halal dan Haram dalam Islam, ter. Mu'ammal Hamidy (Surabaya: Bina Ilmu, 1993). 